\title{
Coexistence and competition of sulfate-reducing and methanogenic populations in an anaerobic hexadecane-degrading culture
}

Ting-Ting Ma', Lai-Yan Liu', Jun-Peng Rui ${ }^{2,3}$, Quan Yuan ${ }^{4}$, Ding-shan Feng ${ }^{5}$, Zheng Zhou ${ }^{1}$, Li-Rong Dai ${ }^{1}$, Wan-Qiu Zeng ${ }^{1}$, Hui Zhang ${ }^{1}$ and Lei Cheng ${ }^{1 *}$ (i)

\begin{abstract}
Background: Over three-fifths of the world's known crude oil cannot be recovered using state-of-the-art techniques, but microbial conversion of petroleum hydrocarbons trapped in oil reservoirs to methane is one promising path to increase the recovery of fossil fuels. The process requires cooperation between syntrophic bacteria and methanogenic archaea, which can be affected by sulfate-reducing prokaryotes (SRPs). However, the effects of sulfate on hydrocarbon degradation and methane production remain elusive, and the microbial communities involved are not well understood.
\end{abstract}

Results: In this study, a methanogenic hexadecane-degrading enrichment culture was treated with six different concentrations of sulfate ranging from 0.5 to $25 \mathrm{mM}$. Methane production and maximum specific methane production rate gradually decreased to 44 and $56 \%$ with sulfate concentrations up to $25 \mathrm{mM}$, respectively. There was a significant positive linear correlation between the sulfate reduction/methane production ratio and initial sulfate concentration, which remained constant during the methane production phase. The apparent methanogenesis fractionation factor $\left(a_{\text {app }}\right)$ gradually increased during the methane production phase in each treatment, the $a_{\text {app }}$ for the treatments with lower sulfate $(0.5-4 \mathrm{mM})$ eventually plateaued at $~ 1.047$, but that for the treatment with 10-25 mM sulfate only reached $\sim 1.029$. The relative abundance levels of Smithella and Methanoculleus increased almost in parallel with the increasing sulfate concentrations. Furthermore, the predominant sulfate reducer communities shifted from Desulfobacteraceae in the low-sulfate cultures to Desulfomonile in the high-sulfate cultures.

Conclusion: The distribution of hexadecane carbon between methane-producing and sulfate-reducing populations is dependent on the initial sulfate added, and not affected during the methane production period. There was a relative increase in hydrogenotrophic methanogenesis activity over time for all sulfate treatments, whereas the total activity was inhibited by sulfate addition. Both Smithella and Methanoculleus, the key alkane degraders and methane producers, can adapt to sulfate stress. Specifically, different SRP populations were stimulated at various sulfate concentrations. These results could help to evaluate interactions between sulfate-reducing and methanogenic populations during anaerobic hydrocarbon degradation in oil reservoirs.

Keywords: Oil reservoirs, Hydrocarbon degradation, Methane production, Sulfate reduction, Microbial interactions

\footnotetext{
*Correspondence: chenglei@caas.cn

${ }^{1}$ Key Laboratory of Development and Application of Rural Renewable Energy, Biogas Institute of Ministry of Agriculture, Section 4-13, Renmin South Road, Chengdu 610041, People's Republic of China

Full list of author information is available at the end of the article
} 


\section{Background}

Crude oil is the most relied-upon source of energy supply worldwide, accounting for $32.9 \%$ of global energy consumption [1]. However, the oil recovery efficiency in most oilfields around the world is commonly less than $40 \%$ [2], indicating that a larger amount of oil trapped in subsurface reservoirs has not been efficiently explored, even with advanced techniques of enhanced oil recovery (EOR) [3]. Geological and geochemical studies suggest that the vast majority of oil reservoirs have undergone biodegradation over millennia, and oil biodegradation in most reservoirs must indeed have been anaerobic in nature [4-6]. The methanogenic degradation of crude oil to methane appears to commonly proceed in oil reservoirs over geological time-scales, and biogenic methane may account for over $20 \%$ of global conventional recoverable gas resources $[5,7,8]$. Many microbial studies in the past twenty decades have demonstrated that aliphatic and aromatic hydrocarbons can be biodegraded in anoxic environments where nitrate, sulfate, and metal ions can function as terminal electron acceptors; when those electron acceptors are limited, the hydrocarbons can be further converted to methane and carbon dioxide in a process known as methanogenic crude oil biodegradation [9]. The methanogenic process has also been observed in oil fields [10-13], which suggests the in situ bioconversion of hydrocarbons in oil reservoirs. As anaerobic microbial communities can play significant roles in increasing the amount of energy recovered and reducing the exploitation cost by converting petroleum hydrocarbons into methane and carbon dioxide [10, 14, 15], an alternative technique called microbial enhanced energy recovery (MEER) was proposed $[14,16]$. However, this process takes several months and even years under laboratory incubation conditions, and may also require much longer time to complete in field-scale experiments for environmental constraints $[10,11,17]$. In addition, the microbial communities commonly utilize a small fraction of crude oil $[10,11,17]$. Hence careful exploration of the oil degradation rate and efficiency are extremely important when considering the prospects of the technique in the future [16].

Methanogenic degradation of hydrocarbons to methane requires at least two different groups of microorganisms (syntrophic bacteria and methanogenic archaea) due to thermodynamic constraints [18]. Hydrocarbon is first degraded and converted into hydrogen and/or acetate by syntrophic bacteria; the byproducts are further converted into methane by methanogens [18]. In addition to methanogenic and syntrophic consortia, sulfatereducing prokaryotes (SRPs), which were first reported in oil reservoirs 90 years ago [19], have also been identified in diverse geographical oil reservoirs and laboratory cultures capable of methanogenic hydrocarbon degradation [12, 20-24]. SRPs not only utilize simple compounds such as $\mathrm{H}_{2} / \mathrm{CO}_{2}$ and acetate but also degrade a variety of complex organic chemicals, such as hydrocarbons and fatty acids, to produce $\mathrm{CO}_{2}$ and/or acetate $[25,26]$. In the presence of sulfate, SRPs are believed to outcompete methanogens in most cases due to their high affinities for common substrates, which divert carbon and the electron flow of organic compounds away from methanogenesis to sulfidogenesis [27-29]. When sulfate is absent or limiting, some SRPs are also able to survive by cooperating with methanogens and syntrophic bacteria [25]. Sulfate is a common constituent in oil fields, with concentrations ranging from zero to several thousand milligrams per liter $[24,30]$, and is a key factor affecting the activity of SRPs and the interactions between methanogenic populations and SRPs. Several studies of the methanogenic degradation of alkanes have reported that sulfate concentrations less than $2-5 \mathrm{mM}$ can enhance alkanedependent methanogenesis, while high concentrations of sulfate $(10-22 \mathrm{mM})$ decreased the methanogenesis rate $[11,15,31]$. However, the interactions between methanogenic populations and SRPs during alkane degradation have not yet been fully exploited, and the contribution of them to alkane degradation has not been quantitatively described.

Previous studies have revealed that a series of novel uncultured bacteria dominated in methanogenic alkane-degrading cultures enriched from oil fields and oil-contaminated sediments [20, 21]. Among them, Syntrophaceae-affiliated members have always been detected $[13,15,32-35]$ and have been identified as key players in alkane activation and oxidation [33, 34]. Metagenomic and single-cell genomic analysis suggested that Syntrophaceae activates the initial degradation of hexadecane by fumarate addition [36-38], which was further demonstrated by direct detection of methyl pentadecyl succinic acid and methyl tetradecyl succinic acid in methanogenic cultures amended with hexadecane and pentadecane, respectively [39]. The archaeal communities in the above-mentioned cultures were composed of aceticlastic and hydrogenotrophic methanogens, but the phylogenetic compositions and abundance levels of two types of methanogens varied in different cultures [11, 13, 15, 32-35, 40]. In addition, SRPs, such as Desulfovibrionales, Desulfuromonadales, and Desulfobacterales, also coexisted in Syntrophaceae-dominant, alkane-degrading cultures [15, 32, 34, 35]. However, it remains unclear how methanogenic microbial communities, including syntrophic alkane degraders and methane producers, respond to sulfate stress and which phylogenetic groups of SRPs are responsible for sulfate reduction at different sulfate concentrations. 
Therefore, we incubated a highly enriched, methanogenic hexadecane-degrading culture with amendment of different sulfate concentrations $(0.5,2,4,10,15$, and $25 \mathrm{mM}$ ) to describe the carbon and electron flow between methane production and sulfate reduction during anaerobic hexadecane degradation and to evaluate the effects of sulfate on the methane production pathway. Cultureindependent molecular techniques (terminal restriction fragment length polymorphism [T-RFLP], cloning and MiSeq sequencing of $16 \mathrm{~S}$ rRNA genes) were applied to assess the shifts in microbial community compositions.

\section{Results}

\section{Methane production and sulfate reduction}

Methane production began after a lag phase of approximately 120 days and increased over a total incubation period of 421 days in the cultures in which hexadecane and variable concentrations of sulfate were present (Fig. 1a). A maximum methane production of $3.52 \pm 0.02 \mathrm{mmol}$ was observed in the culture with $0.5 \mathrm{mM}$ sulfate. Methane production gradually decreased with increasing sulfate concentration and dropped to $1.93 \pm 0.04 \mathrm{mmol}$ in the $25 \mathrm{mM}$ sulfate culture (Fig. 1a).

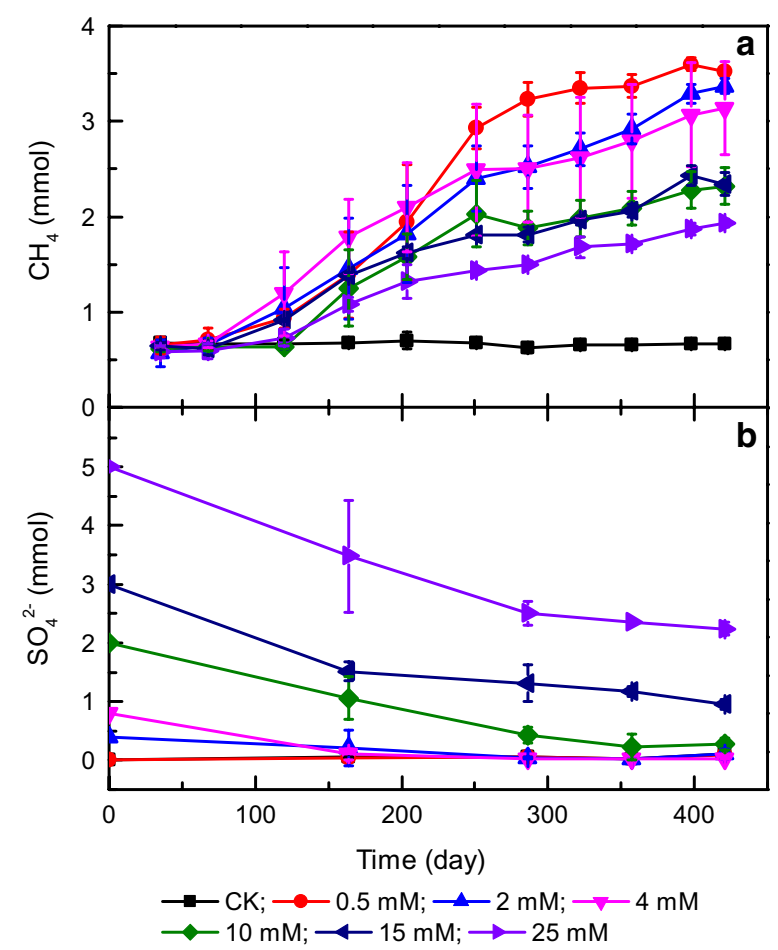

Fig. 1 Methane production (a) and sulfate consumption (b) in cultures amended with different sulfate concentrations. CK, culture without hexadecane and sulfate addition; 0.5, 2, 4, 10, 15, and $25 \mathrm{mM}$, represent cultures amended with hexadecane and $0.5,2,4,10,15$, and $25 \mathrm{mM}$ sulfate, respectively. Values represent means and standard errors ( $n=2-3$ replicates)
The maximum specific methane production rate $\left(\mu_{\max }\right)$ declined from $0.41 \pm 0.005$ month $^{-1}$ in the $0.5 \mathrm{mM}$ sulfate culture to $0.20 \pm 0.02 \mathrm{month}^{-1}$ in the $25 \mathrm{mM}$ sulfate culture (Table 1). In contrast, the hexadecane- and sulfate-free culture only accumulated an average of $0.66 \mathrm{mmol}$ of methane during the entire incubation period (Fig. 1a). The amount of residual hexadecane decreased from $0.074 \pm 0.052 \mathrm{mmol}$ for the $0.5 \mathrm{mM}$ sulfate culture to $0.015 \pm 0.006 \mathrm{mmol}$ for the $25 \mathrm{mM}$ sulfate culture at the end of the incubation period (Additional file 1: Figure S1). Correspondingly, sulfate consumption increased from $0.08 \pm 0.01 \mathrm{mmol}$ for the $0.5 \mathrm{mM}$ sulfate culture to $2.66 \pm 0.11 \mathrm{mmol}$ for the $25 \mathrm{mM}$ sulfate culture (Fig. 1b; Table 1). A trace amount of sulfate (an average of $0.1 \mathrm{mM}$ ) was detected in the control culture (data not shown). No volatile fatty acid concentrations were observed above the detection limit of this method (approximately $100 \mu \mathrm{M}$ ) (data not shown).

Assuming total degradation of hexadecane via methanogenesis and/or sulfidogenesis (Eqs. 2 and 3), the percentage of hexadecane carbon recovery averaged $93.9 \pm 9.0 \%$ in the $82.1-101.0 \%$ range (Table 1). The carbon balance of hexadecane consumption linked to sulfidogenic and methanogenic degradation was further evaluated. For every $1 \mathrm{~mol}$ of hexadecane degraded, an equivalent $12.25 \mathrm{~mol}$ of combined methane production and sulfate consumption occurred (Eqs. 2 and 3), consistent with the observed average values of $11.49 \pm 1.11$ in the 10.06-12.37 range (Table 1). However, the estimated contribution of hexadecane degradation through methanogenesis decreased from $88.6 \pm 16.7 \%$ in the $0.5 \mathrm{mM}$ sulfate culture to $31.6 \pm 1.1 \%$ in the $25 \mathrm{mM}$ sulfate culture (Fig. 2a). The decrease in electron flow to methane production was completely compensated by an increase in electron flow to sulfate reduction, which increased from $3.1 \pm 0.6 \%$ in the $0.5 \mathrm{mM}$ sulfate culture to $66.4 \pm 2.6 \%$ in the $25 \mathrm{mM}$ sulfate culture (Fig. $2 \mathrm{a}$ ). The ratio of these two estimates, i.e., the sulfate reduction to methane production ratio, correlated positively with the initial sulfate concentrations $\left(R^{2}=0.94-0.99, p<0.01\right)$ (Fig. 2b). Further analysis revealed that the differences in the regression results were quite small between 164 and 421 days of incubation; the values of the slope coefficients (0.09-0.11) were also similar (Fig. 2b).

\section{Isotopic fractionation of methane incubated at different sulfate concentrations}

Isotopic analysis revealed that the $\delta^{13} \mathrm{C}$ values of methane $\left(\delta^{13} \mathrm{CH}_{4}\right)$ generated were similar at the early stage of methane production (120 days), i.e., averaging $-45.9 \pm 2.2 \%$ (Fig. 3a). With increasing $\mathrm{CH}_{4}$ accumulation, $\delta^{13} \mathrm{CH}_{4}$ continued to decrease and plateaued at $-61.5 \pm 1.7$ and $-50.7 \pm 1.2 \%$ for the $0.5-4 \mathrm{mM}$ and 10-25 mM sulfate cultures, respectively, after 421 days 


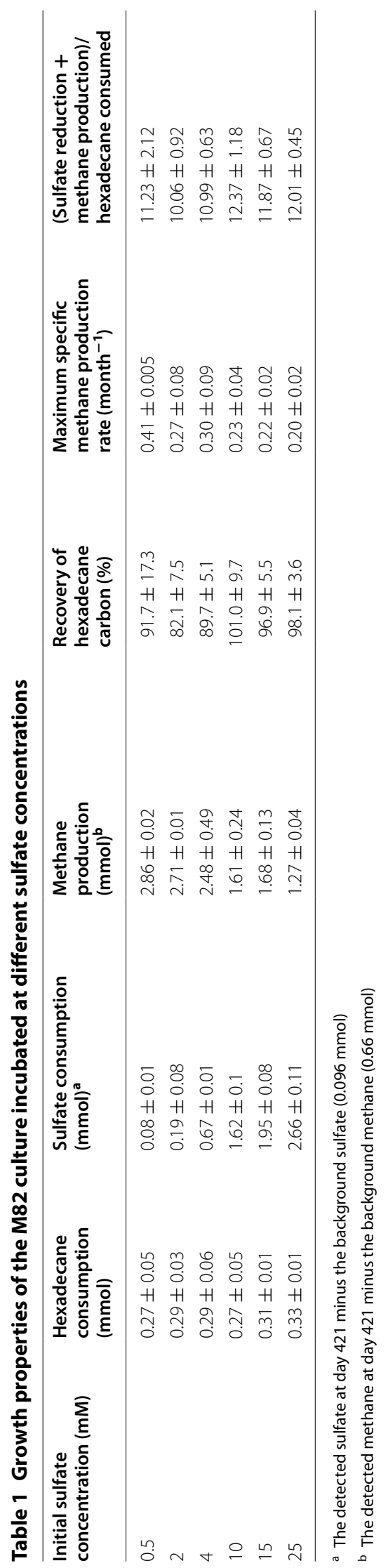




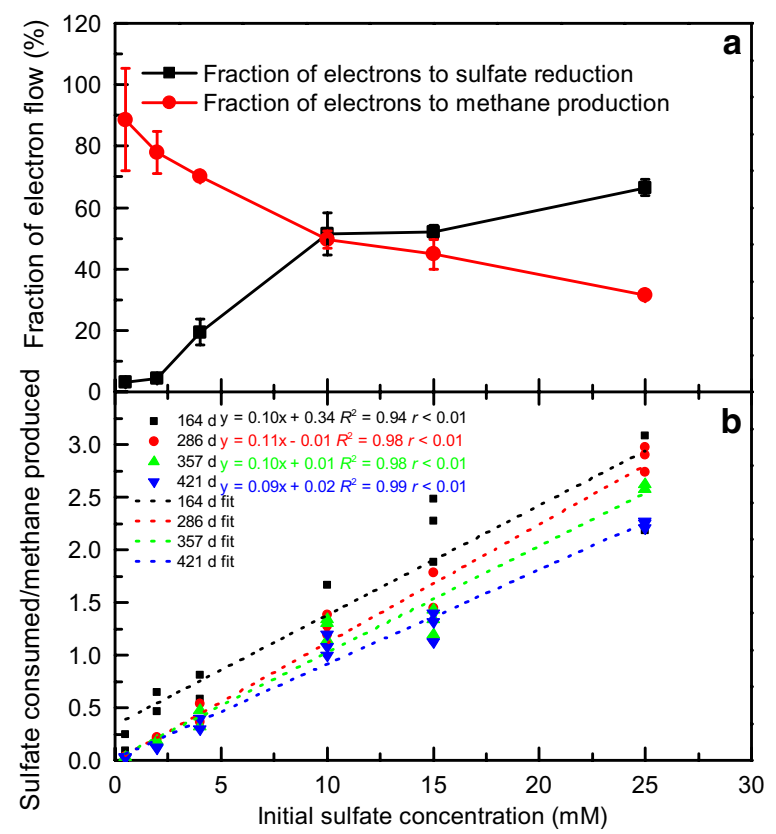

Fig. 2 Effects of sulfate on electron flow (a) and ratio of sulfate reduction/methane production (b). Values represent means and standard errors ( $n=2-3$ replicates)

of incubation (Fig. 3a). The $\mathrm{CO}_{2}$ concentrations measured in the headspace were used for isotopic analysis, since $\mathrm{CO}_{2}$ rather than bicarbonate is the active substrate for hydrogenotrophic methanogenesis [41]. The $\delta^{13} \mathrm{C}$ value of carbon dioxide $\left(\delta^{13} \mathrm{CO}_{2}\right)$ was $-28.7 \pm 2.8 \%$ in all sulfate addition cultures after 120 days of incubation. The $\delta^{13} \mathrm{CO}_{2}$ values continued to increase during incubation and plateaued at $-17.0 \pm 3.4$ and $-22.8 \pm 1.9 \%$ for the $0.5-4$ and $10-25 \mathrm{mM}$ sulfate cultures, respectively (Fig. 3b). According to Eq. 1, reported by Whiticar et al. [42] the $\delta^{13} \mathrm{C}$ values of $\mathrm{CH}_{4}$ and $\mathrm{CO}_{2}$ were used to compute the apparent fractionation factors $\left(\alpha_{\text {app }}\right)$. The $\alpha_{\text {app }}$ values initially remained at $1.017 \pm 0.004$ during the early stage and increased to $1.047 \pm 0.004$ in the $0.5-4 \mathrm{mM}$ sulfate cultures. However, the $\alpha_{\text {app }}$ value had only increased to $1.029 \pm 0.003$ in the $10-25 \mathrm{mM}$ sulfate cultures at the end of incubation (Fig. 3c).

$$
\alpha_{\text {app }}=\left(\delta^{13} \mathrm{CO}_{2}+1000\right) /\left(\delta^{13} \mathrm{CH}_{4}+1000\right)
$$

\section{Microbial community structures and functions \\ Archaeal community}

The archaeal communities of the cultures with different sulfate concentrations were mainly composed of Methanothrix (T-RFs 228, 284 and 495 bp), Methanolinea (T-RFs 84 and $393 \mathrm{bp}$ ), Methanobacteriaceae (T-RF $92 \mathrm{bp}$ ), and Methanoculleus (T-RF 186 bp) (Fig. 4a; Table 2). Methanothrix was one of the dominant phylotypes (Fig. 4a). However, Methanolinea, which was represented by

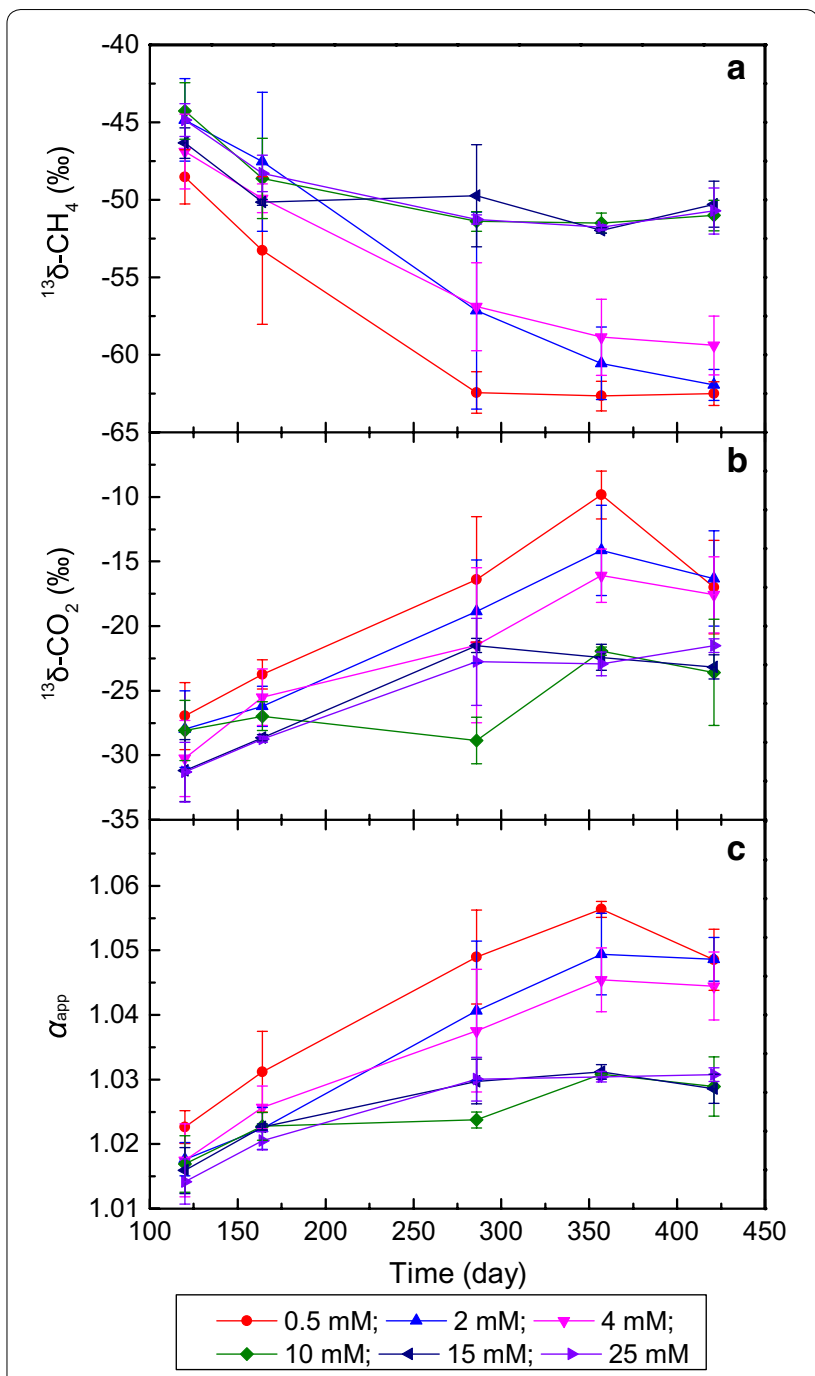

Fig. 3 Values of $\delta^{13} \mathrm{CH}_{4}(\mathbf{a}), \delta^{13} \mathrm{CO}_{2}(\mathbf{b})$ and apparent fractionation $\mathrm{fac}-$ tors $\left(a_{C}\right)(\mathbf{c})$. CK, culture without hexadecane and sulfate addition; 0.5 , $2,4,10,15$, and $25 \mathrm{mM}$ represent cultures amended with hexadecane and $0.5,2,4,10,15$, and $25 \mathrm{mM}$ sulfate, respectively. Values represent means and standard errors ( $n=2-3$ replicates)

the 84-bp T-RF, increased substantially over time and became the predominant phylotype in the $0.5 \mathrm{mM}$ sulfate culture at the end of incubation (Fig. 4a). The Methanoculleus populations also increased in all sulfate cultures and became the second dominant phylotype in the 2-25 mM sulfate cultures (Fig. 4a). Pearson correlation analysis revealed that the Methanoculleus and Methanolinea populations (T-RF $84 \mathrm{bp}$ ) were significantly and positively correlated with methane production $(r=0.454$ and 0.352 , respectively, $p<0.01$ ) (Table 3). Methanoculleus also exhibited a positive correlation with sulfate consumption ( $r=0.351, p<0.05)$, whereas Methanolinea (T-RF $84 \mathrm{bp}$ ) had a significantly negative correlation $(r=-0.421, p<0.01)$ (Table 3). ANOSIM indicated that 


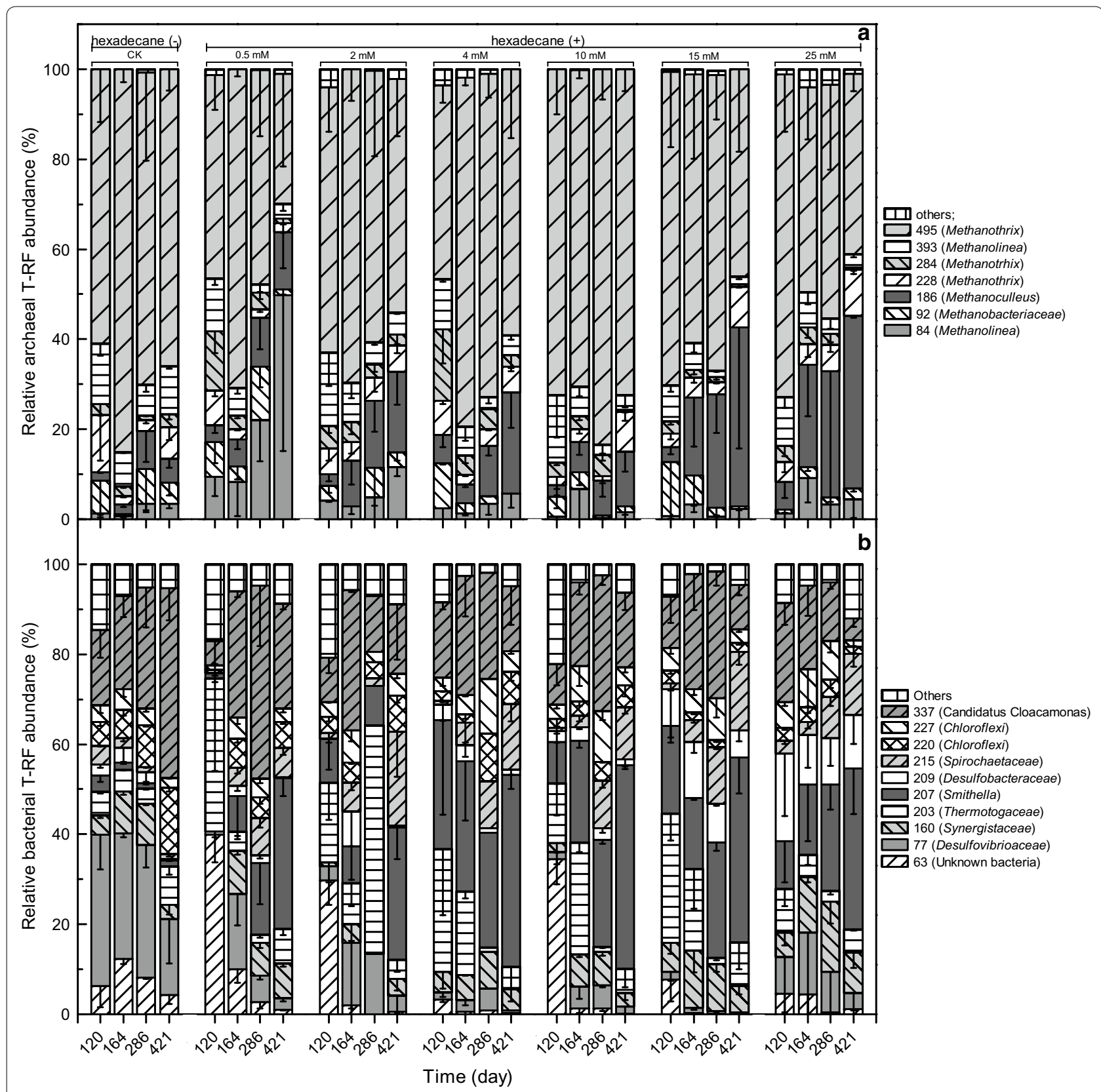

Fig. 4 Relative abundance levels of T-RFs of archaeal (a) and bacterial (b) 16S rRNA genes. CK, culture without hexadecane and sulfate addition; 0.5, $2,4,10,15$, and $25 \mathrm{mM}$ represent cultures amended with hexadecane and 0.5, 2, 4, 10, 15, and $25 \mathrm{mM}$ sulfate, respectively. Values represent means and standard errors ( $n=2-3$ replicates). The phylogenetic positions of bacterial phylotypes represented by T-RFs are as referenced in our previous report [34]

the archaeal communities from the 0.5 and $2 \mathrm{mM}$ sulfate cultures were more similar to each other than cultures in which 4-25 mM sulfate was added (Table 4).

\section{Bacterial community}

The most common bacterial groups were members of Smithella (T-RF 207 bp), Synergistaceae (T-RF 160 bp),
Thermotogaceae (T-RF 203 bp), Spirochaetaceae (T-RF 215 bp), Chloroflexi (T-RFs 220 and 227 bp), Candidatus Cloacamonas (T-RF $337 \mathrm{bp}$ ), and unknown bacteria (T-RF $63 \mathrm{bp)}$ (Fig. 4b). These bacterial groups, with the exception of the 63-bp T-RF identified here, have been proposed as the core microbiome of the methanogenic hexadecanedegrading culture M82 without sulfate addition [12]. 
Table 2 Archaeal 16S rRNA gene clone libraries

\begin{tabular}{|c|c|c|c|c|c|c|}
\hline \multirow[t]{2}{*}{ Phylogenetic group } & \multicolumn{3}{|c|}{ In silico T-RF (No. of clones) ${ }^{a}$} & \multirow{2}{*}{$\begin{array}{l}\text { Clone type (GenBank } \\
\text { Accession Number) }\end{array}$} & \multirow[t]{2}{*}{ Closest species } & \multirow[t]{2}{*}{ Similarity (\%) } \\
\hline & CK & $0.5 \mathrm{mM}$ & $25 \mathrm{mM}$ & & & \\
\hline \multirow[t]{3}{*}{ Methanosaetaceae } & $228(2)$ & & & A4-6 (KJ735834) & \multirow{3}{*}{$\begin{array}{l}\text { Methanosaeta harundinacea } \\
\text { 6Ac; NR_102896 }\end{array}$} & 99 \\
\hline & $495(12)$ & \multirow[t]{2}{*}{$495(11)$} & \multirow[t]{2}{*}{$495(10)$} & A18-26 (KJ735844) & & 96 \\
\hline & $791(1)$ & & & A80-6 (KR297252) & & 82 \\
\hline \multirow[t]{2}{*}{ Methanomicrobiaceae } & & $186(3)$ & $186(12), 187(1)$ & A4-7 (KJ735835) & \multirow{2}{*}{$\begin{array}{l}\text { Methanoculleus receptaculi ZC-2; } \\
\text { NR_043961 }\end{array}$} & 99 \\
\hline & & & $186(2)$ & A18-28 (KJ735845) & & 95 \\
\hline \multirow[t]{2}{*}{ Methanoregulaceae } & & $84(9)$ & & A4-21 (KJ735839) & \multirow{2}{*}{$\begin{array}{l}\text { Methanolinea tarda NOBI-1; } \\
\text { NR_028163 }\end{array}$} & 98 \\
\hline & $84(1), 393(1)$ & & & A80-2 (KJ735846) & & 97 \\
\hline \multirow[t]{2}{*}{ Methanobacteriaceae } & $93(1), 95(6)$ & & & A80-8 (KJ735840) & $\begin{array}{l}\text { Methanothermobacter thermau- } \\
\text { totrophicus CaT2; AP011952 }\end{array}$ & 83 \\
\hline & & $91(1), 92(5)$ & & A4-27 (KJ735841) & $\begin{array}{l}\text { Methanobacterium beijingense } \\
4-1 ; \text { AY552778 }\end{array}$ & 99 \\
\hline
\end{tabular}

a The 16S rRNA gene clone libraries were retrieved from the cultures after 421 days of incubation. CK, the culture without hexadecane and sulfate addition; 0.5 mM: the culture only amended with hexadecane and $0.5 \mathrm{mM}$ sulfate; $25 \mathrm{mM}$ : the culture amended with hexadecane and $25 \mathrm{mM}$ sulfate

Table 3 Pearson correlations of T-RFs with methane production and sulfate consumption

\begin{tabular}{|c|c|c|c|c|}
\hline Domain & Phylogenetic position & T-RF (bp) & Methane production & Sulfate consumption \\
\hline \multirow[t]{7}{*}{ Archaeal domain } & Methanolinea & 84 & $0.454^{\mathrm{a}}$ & $-0.421^{\mathrm{a}}$ \\
\hline & Methanolinea & 393 & $-0.659^{a}$ & -0.089 \\
\hline & Methanobacteriaceae & 92 & -0.073 & $-0.337^{b}$ \\
\hline & Methanoculleus & 186 & $0.352^{\mathrm{a}}$ & $0.351^{b}$ \\
\hline & Methanosaeta & 228 & 0.082 & $0.528^{\mathrm{a}}$ \\
\hline & Methanosaeta & 284 & $-0.274^{b}$ & -0.206 \\
\hline & Methanosaeta & 495 & -0.259 & 0.048 \\
\hline \multirow[t]{10}{*}{ Bacterial domain } & Unknown bacteria & 63 & $-0.482^{\mathrm{a}}$ & -0.161 \\
\hline & Desulfovibrionaceae & 77 & -0.158 & 0.047 \\
\hline & Synergistaceae & 160 & -0.068 & $0.326^{b}$ \\
\hline & Thermotogaceae & 203 & $-0.370^{\mathrm{a}}$ & -0.188 \\
\hline & Smithella & 207 & $0.532^{\mathrm{a}}$ & $0.314^{b}$ \\
\hline & Desulfobacteraceae & 209 & $-0.333^{\mathrm{a}}$ & $0.428^{\mathrm{a}}$ \\
\hline & Spirochaetaceae & 215 & $0.715^{\mathrm{a}}$ & 0.136 \\
\hline & Chloroflexi & 220 & $0.467^{\mathrm{a}}$ & $-0.443^{\mathrm{a}}$ \\
\hline & Chloroflexi & 227 & 0.029 & -0.061 \\
\hline & Candidatus Cloacamonas & 337 & $0.262^{b}$ & $-0.499^{\mathrm{a}}$ \\
\hline
\end{tabular}

\footnotetext{
${ }^{a}$ Correlation is significant at the 0.01 level (2-tailed)
}

${ }^{\mathrm{b}}$ Correlation is significant at the 0.05 level (2-tailed)

Table 4 ANOSIM pairwise comparison of similarities among archaeal communities following the addition of different sulfate concentrations

\begin{tabular}{llllll}
\hline Sulfate concentration $(\mathbf{m M})$ & $\mathbf{0 . 5}$ & $\mathbf{2}$ & $\mathbf{4}$ & $\mathbf{1 0}$ & $\mathbf{1 5}$ \\
\hline 0.5 & & & & & \\
2 & -0.023 & & & \\
4 & $0.156^{\mathrm{a}}$ & -0.050 & & \\
10 & $0.319^{\mathrm{a}}$ & 0.136 & -0.015 & & \\
15 & $0.213^{\mathrm{a}}$ & 0.020 & -0.014 & 0.036 & -0.001 \\
25 & $0.150^{\mathrm{a}}$ & -0.030 & 0.025 & 0.122 & \\
\hline
\end{tabular}

${ }^{\text {a }}$ Value is significant at the 0.05 level 
Table 5 ANOSIM pairwise comparison of similarities among bacterial communities following the addition of different sulfate concentrations

\begin{tabular}{lllllll}
\hline Sulfate concentration $(\mathbf{m M})$ & $\mathbf{0 . 5}$ & $\mathbf{2}$ & $\mathbf{4}$ & $\mathbf{1 0}$ & $\mathbf{1 5}$ & $\mathbf{2 5}$ \\
\hline 0.5 & & & & & & \\
2 & $0.483^{\mathrm{a}}$ & & & & \\
4 & $0.996^{\mathrm{a}}$ & 0.056 & & & \\
10 & $0.647^{\mathrm{a}}$ & 0.013 & -0.092 & & \\
15 & $0.995^{\mathrm{a}}$ & $0.194^{\mathrm{a}}$ & 0.045 & 0.090 & \\
25 & $0.96^{\mathrm{a}}$ & $0.247^{\mathrm{a}}$ & $0.287^{\mathrm{b}}$ & $0.217^{\mathrm{b}}$ & 0.085 \\
\hline
\end{tabular}

a Value is significant at the 0.05 level

b Value is significant at the 0.01 level

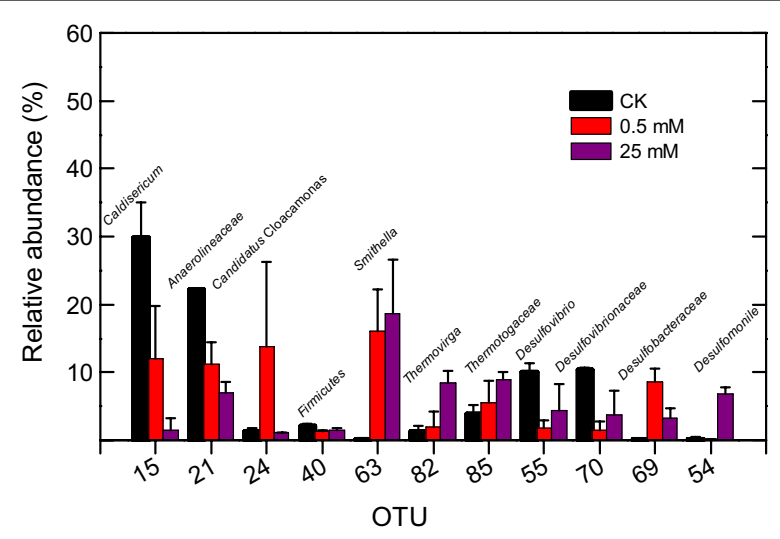

Fig. 5 Relative abundance levels of top 11 OTUs. CK, culture without hexadecane and sulfate addition; 0.5 and $25 \mathrm{mM}$ represent cultures amended with hexadecane and 0.5 and $25 \mathrm{mM}$ sulfate, respectively. Values represent means and standard errors ( $n=2$ replicates)

Members of the core microbiome were positively associated with methane production, except for Thermotogaceae, which was negatively associated with methane production $(p<0.01)$ (Table 3$)$. Only Smithella exhibited positive associations with methane production and sulfate consumption (Table 3). Desulfobacteraceae was negatively associated with methane production but was positively correlated with sulfate consumption $(p<0.01)$ (Table 3). ANOSIM indicated that the bacterial communities could be divided into three clusters corresponding to the $0.5,2-10$, and $15-25 \mathrm{mM}$ sulfate cultures, respectively (Table 5 ). The bacterial community structure was further evaluated through high-throughput sequencing of the $16 \mathrm{~S}$ rRNA gene. In total, 318,839 reads with an average length of $413 \mathrm{bp}$ were retrieved from the control and the 0.5 and $25 \mathrm{mM}$ sulfate cultures at the end of incubation (Additional file 2: Table S1). The top 11 operational taxonomic units (OTUs) accounting for $62-75 \%$ of the sequences are shown in Fig. 5. Members of Caldisericum (an average of 30\%), Anaerolineaceae (22\%), and Desulfovibrionaceae ( $20 \%$, two OTUs) were predominant in the control without sulfate and hexadecane addition (Fig. 5). The dominant phylotypes in the $0.5 \mathrm{mM}$ sulfate addition cultures belonged to Smithella (16.1\%), Candidatus Cloacamonas (13.8\%), Caldisericum (12.0\%), unclassified Anaerolineaceae (11.2\%), Desulfobacteraceae (8.6\%), and Thermotogaceae (5.5\%), similar to the bacterial T-RFLP profile (Figs. 4b, 5). In contrast, only Smithella (18.7\%), Thermotogacea (8.9\%), and Anaerolineaceae (7.0\%) were retained as the dominant members in the $25 \mathrm{mM}$ sulfate culture (Fig. 5). The relative abundance of Thermovirga increased to above $7 \%$ in the high-sulfate culture (Fig. 5). Among the four known SRPs (Desulfomonile, unclassified Desulfobacteraceae and two OTUs in family Desulfovibrionaceae), members of Desulfovibrionaceae were dominant (19.3-21.5\%, two OTUs) in the control (Fig. 5). Unclassified Desulfobacteraceae was predominant (7.2$10.0 \%)$ in the $0.5 \mathrm{mM}$ sulfate culture, whereas Desulfomonile $(6.1-7.5 \%)$ was predominant in the $25 \mathrm{mM}$ sulfate culture (Fig. 5).

\section{Discussion}

Impacts of sulfate on hexadecane degradation and methane production

The results of this study join those of a previous body of reports demonstrating that methanogenic cultures can degrade alkanes anaerobically in the presence of sulfate $[11,15,31]$. Methane production was enhanced under low-sulfate concentrations $(<2-5 \mathrm{mM})[15,31]$, whereas significant inhibition was observed at sulfate concentrations greater than $5 \mathrm{mM}$ [31]. Gieg et al. [11] reported that the extent of methanogenic degradation of crude oil alkanes was not affected by sulfate in the $10 \mathrm{mM}$ range, but the methane production rate slightly decreased. The results of this study demonstrated that the rate and extent of methane production were gradually inhibited by increasing sulfate concentration (Fig. 1). However, the presence of excessive sulfate at $25 \mathrm{mM}$, which is higher than the $21 \mathrm{mM}$ needed for complete conversion of hexadecane to $\mathrm{CO}_{2}$ through sulfate reduction, did not completely inhibit methane production (Eq. 2). The 
concurrent methane production and sulfate reduction in the excessive presence of sulfate may be attributed to the adequate supply of noncompetitive substrates or an abundance of competitive substrates for the syntrophs and methanogens [43]. However, the possibility of cooperation between the incomplete-oxidizing sulfate reducers and methanogens cannot be ignored if incomplete oxidation of organic intermediates into $\mathrm{H}_{2}$ or acetate through sulfate reduction presented in the cultures [44]. This study also demonstrated that sulfate reduction increased hydrocarbon degradation efficiency, although the enhancement may not be directly used to address questions of methanogenic and sulfidogenic competition $[45,46]$. The increased activity of sulfate reduction after the treatment with increased sulfate concentration probably enhanced $\mathrm{H}_{2}$ conversion rate and caused a much lower hydrogen concentration below the threshold value for hydrogenotrophic methanogens [44, 47, 48], which may facilitate the syntrophic alkane oxidation process from a thermodynamics standpoint [18].

The concept of "electron flow" was introduced by Isa et al. [49] to quantify the competition between methanogenesis and sulfidogenesis. The most common explanation for the electron distribution between sulfate reduction and methane production during organic substrate degradation is the effect of the $\mathrm{COD} / \mathrm{SO}_{4}{ }^{2-}$ ratio [49-51], which also includes other factors, such as $\mathrm{H}_{2} \mathrm{~S}$, substrate concentration, and inoculum volume [49]. As expected, electron flux toward sulfidogenesis increased with increasing sulfate concentrations in this study (Fig. 2a). However, unlike most previous work showing how electron flow can be affected by the COD/ $\mathrm{SO}_{4}{ }^{2-}$ ratio [50-53], the relative distribution of electrons between the SRPs and the methanogenic populations depended on the initial sulfate addition and remained constant during methane production (Fig. $2 \mathrm{~b}$ ), which has not been reported before. The results suggested that the concentration of sulfate could be an effective indicator of hexadecane metabolism pathway under mixed electron acceptors conditions. Giving the complex composition of crude oil and diverse electron acceptors present in oil reservoirs, it is also necessary in the future to evaluate the in situ effects of sulfate on the carbon and electron flow during methanogenic crude oil degradation, which could aid in predicting the biomethane potential of crude oil in field trials.

\section{Impact of sulfate on the methanogenic pathway}

The $\alpha_{\text {app }}$ is a generally accepted index to coarsely estimate the dominant methane production pathway [42], with values above 1.065 and below 1.025 proposed to represent hydrogenotrophic and aceticlastic methanogenesis, respectively, according to recent reports $[54,55]$.
However, the $\alpha_{\text {app }}$ value apparently changes according to species and growth conditions, and the values measured in various cultures of hydrogenotrophic methanogens range between 1.031 and 1.077 [56, 57]. Two methanogen genera, Methanosarcina and Methanothrix, are capable of performing aceticlastic reactions [58], whereas only Methanothrix species were observed in this study (Fig. 4a), and the fractionation factor of this genus during aceticlastic methanogenesis is less than 1.01 [56, 59]. Moreover, the acetate concentration was always lower than the threshold value $(100 \mu \mathrm{M})$ during incubation, indicating that carbon isotope fractionation did not occur during the conversion of acetate to $\mathrm{CH}_{4}$ by aceticlastic methanogens [60]. Therefore, the increase in $\alpha_{\text {app }}$ observed during the incubation of all sulfate addition cultures likely revealed that $\mathrm{CO}_{2}$ reduction was the predominant methanogenic pathway, although acetate disproportionation would also contribute to hexadecane degradation. Meanwhile, $\alpha_{\text {app }}$ decreased gradually with increasing sulfate concentration (Fig. 3c), indicating that sulfate reduction often outcompetes hydrogenotrophic methanogenesis for $\mathrm{H}_{2}$ utilization from thermodynamic and kinetic points of view $[48,49]$.

\section{Microbial community response to sulfate stress}

The aceticlastic Methanothrix was the dominant archaea, not only in the hexadecane- and sulfate-containing cultures but also in the control culture in which hexadecane and sulfate were not added (Fig. 4a). The dominant Methanothrix did not show a positive relationship with either methane production or sulfate reduction (Table 3). These observations indicated that Methanothrix may play a minor role in methanogenic hexadecane degradation, which was not only supported by the aforementioned changes in methanogenic communities but also by increasing $\alpha_{\text {app }}$ values over time in all sulfate treatments. Regardless, Methanothrix may still play a role by leaking $\mathrm{H}_{2}$ from acetate degradation to SRPs for sulfate reduction [61]. Both Methanoculleus and Methanolinea species, which use $\mathrm{H}_{2} / \mathrm{CO}_{2}$ for methanogenesis [62, 63], were positively associated with methane production (Fig. 4a; Table 3). The Methanoculleus populations steadily increased with increasing initial sulfate concentrations and became the second most abundant after Methanothrix in the 2-25 $\mathrm{mM}$ sulfate cultures. This increase could be explained by the fact that Methanoculleus may have a greater affinity than other hydrogenotrophic methanogens for $\mathrm{H}_{2}$ [64] or the fact that Methanoculleus is involved in the syntrophic alkane oxidation process, together with SRPs [34].

Smithella is the predominant bacterial phylotype responsible for alkane degradation under methanogenic conditions [33, 34]. Detection of the ass A gene and 
methyl pentadecyl succinic acid in the methanogenic hexadecane-degrading culture has demonstrated that Smithella can initiate alkane degradation via fumarate addition [39]. However, no $d s r$-like gene was detected in the binned genome of strain M82_1 [39]. The observation of a positive correlation between Smithella abundance and sulfate addition (Fig. 4b; Table 3) may reflect cooperation rather than competition between syntrophic alkane degraders and SRPs, as supported by reported increased hexadecane degradation efficiency with increasing sulfate consumption (Additional file 1: Figure S1). The core bacterial phylotypes affiliated with Spirochaetaceae, Chloroflexi, Candidatus Cloacamonas, and Thermotogaceae were proposed to play roles as either secondary degraders during the degradation of hexadecane [12] and terephthalate [65] or contributors to scavenging anabolic products (protein and lipids), presumably derived from detrital microbial biomass [65]. Most of these bacteria were positively correlated with methane production, but their relationships with sulfate reduction were either negative or irrelevant (Table 3), which may reflect the competition of these phylotypes with SRPs.

SRPs in the methanogenic cultures have the capacity to cooperate with methanogens and syntrophic bacteria under sulfate-free conditions but also possess robustness to compete with these organisms through sulfate reduction when sulfate becomes available [66]. The abundance levels of unclassified Desulfobacteraceae (OTU 69) and Desulfomonile (OTU 54) increased, and these genera became the predominant SRPs in the low- and high-sulfate addition cultures, respectively (Fig. 5). Most members of Desulfobacteraceae can utilize sulfate and acetate as electron acceptors and carbon sources, respectively, and some can oxidize organic substrates completely to $\mathrm{CO}_{2}$, whereas others perform an incomplete oxidation of organic substrates to acetate [67]. Desulfomonile spp., known as dehalogenators, is also capable of $\mathrm{H}_{2}$ scavenging, and $\mathrm{H}_{2}$ uptake can increase by more than fourfold when sulfate is used as an electron acceptor [47]. These findings suggest that the response of the sulfate reduction bacterial community to sulfate varies according to sulfate concentrations, although their ecophysiological roles in methanogenic hexadecane-degrading cultures in the presence of sulfate require further examination.

\section{Conclusions}

This study not only demonstrated the competition and coexistence of sulfate-reducing and methanogenic populations during anaerobic hexadecane degradation processes, but also revealed a linear positive relationship between the ratio of sulfate reduction/methane production and initial sulfate concentration. The removal efficiency of hexadecane could be enhanced by increased sulfate addition, although the amount of methane accumulation decreased. $\mathrm{CO}_{2}$ reduction was the dominant methanogenic pathway, but the activity was inhibited by increasing sulfate addition. Both Smithella and Methanoculleus, the key alkane degraders and methane producers, could be adapted to the sulfate stress, and different SRP populations were stimulated at various sulfate concentrations. Taken together, our results would help to understand the interactions between methanogenic populations and SRPs during alkane degradation under mixed electron acceptors conditions.

\section{Methods}

\section{Culture and growth conditions}

A methanogenic hexadecane-degrading enrichment culture was derived from oily sludge-contaminated sediment from the Shengli oil field in eastern China [34]. The culture was inoculated $(20 \%, \mathrm{vol} / \mathrm{vol})$ into a modified freshwater medium and dispensed into 600-ml vials under an atmosphere of $\mathrm{N}_{2}(99.999 \%)$ gas, where $100 \mu \mathrm{l}$ of hexadecane (99\%, approximately $0.34 \mathrm{mmol}$ ), $2 \mathrm{ml}$ of 2,2,4,4,6,8,8-heptamethylnonane (HMN), and various concentrations of sodium sulfate (giving final concentrations of $0.5,2,4,10$, 15 and $25 \mathrm{mM}$ ) were added. Neither hexadecane nor sulfate was added to the control culture. The cultures were reduced with $\mathrm{Na}_{2} \mathrm{~S} \cdot 9 \mathrm{H}_{2} \mathrm{O}(0.03 \%)$, and the $\mathrm{pH}$ was adjusted to $7.0 \pm 0.2$ by the addition of $\mathrm{HCl}$ or $\mathrm{NaOH}$ solutions prior to incubation. The vials in each set were prepared in triplicate and statically incubated at $35^{\circ} \mathrm{C}$ in the dark.

\section{Chemical methods}

Methane was measured using a gas chromatograph (Agilent 7820A, USA) with a thermal conductivity detector, as previously described [12]. The maximum specific methane production rates $\left(\mu_{\max }\right)$ were calculated [68] from the fitting methane production curves based on a statistical model of Slogistic 1 using ORIGINPRO 8.5 software (OriginLab, USA) The carbon isotopic compositions of $\mathrm{CH}_{4}$ and $\mathrm{CO}_{2}$ were determined using an IsoPrime100 mass spectrometer (United Kingdom) [34]. The liquid cultures (2-8 ml) were carefully aspirated into tubes using anoxic, sterilized syringes, and were centrifuged at $12,000 \times g$ for $5 \mathrm{~min}$ at $4{ }^{\circ} \mathrm{C}$. The supernatants were collected and stored at $-40{ }^{\circ} \mathrm{C}$ for future analysis of sulfate and volatile fatty acid (VFA) concentrations. The cell pellets were harvested and stored at $-80{ }^{\circ} \mathrm{C}$ for microbial community composition analysis (see below). The sulfate concentration was measured using ion chromatography (Metrohm ICS 3000, Switzerland) with a conductivity detector. The liquid samples were diluted 10-fold with deionized water and pretreated using Cleanert IC-RP filtration columns (Agela Technologies, China) before analysis. The eluent contained $30 \mathrm{mM} \mathrm{NaOH}$, and the flow rate was $1.3 \mathrm{ml} / \mathrm{min}$. VFAs were analyzed by gas 
chromatography (GC) (Agilent 7890A, USA) with a flame ionization detector (FID) and a DB-FFAP column [69]. The residual hexadecane after 421 days of incubation was extracted using a mixture of $n$-hexane and acetone $(1: 1, \mathrm{v} / \mathrm{v})$ according to a previous report [40]. A final concentration of $300 \mathrm{mg} / \mathrm{l}$ pristine was also added before extraction to evaluate the recovery efficiency of the method. The extract was analyzed by GC (Agilent 7890A, USA) using a DB-5MS capillary GC column $(30 \mathrm{~m} \times 0.53 \mathrm{~mm} \times 1.5 \mu \mathrm{m})$. The GC injector and FID temperatures were set to 280 and $250{ }^{\circ} \mathrm{C}$, respectively. The oven temperature program began at $60^{\circ} \mathrm{C}$ for $2 \mathrm{~min}$ and increased to $300{ }^{\circ} \mathrm{C}$ at a rate of $12{ }^{\circ} \mathrm{C}$ per min, where it remained for $10 \mathrm{~min}$. The carrier gas was hydrogen $(99.999 \%)$ at a flow rate of $36 \mathrm{ml} / \mathrm{min}$. The hexadecane concentration was determined from the external calibration curve generated from $n$-heptadecane, which was calibrated using the linear equation derived from the peak areas.

\section{Electron flow distribution between sulfate reduction and methane production}

The stoichiometric energy-balance equation for the complete oxidation of hexadecane via methanogenesis (Eq. 2) or coupled to sulfidogenesis (Eq. 3) can be written according to previous reports, when cell growth was not taken into consideration $[15,70]$.

$$
\begin{aligned}
& \mathrm{C}_{16} \mathrm{H}_{34}+7.5 \mathrm{H}_{2} \mathrm{O} \rightarrow 12.25 \mathrm{CH}_{4}+3.75 \mathrm{CO}_{2} \\
& \mathrm{C}_{16} \mathrm{H}_{34}+12.25 \mathrm{SO}_{4}^{2-}+24.5 \mathrm{H}^{+} \\
& \quad \rightarrow 12.25 \mathrm{H}_{2} \mathrm{~S}+16 \mathrm{CO}_{2}+17 \mathrm{H}_{2} \mathrm{O}
\end{aligned}
$$

The distribution of electron flow between sulfidogenic and methanogenic reactions can be calculated from the amounts of sulfate reduced $(S)$ and methane produced $(M)$ [49]. Percent electron flow via methane production was calculated as $(M)=[M /(M+S)] \times 100$; percent electron flow via sulfate reduction was calculated as $(S)=[S /(M+S)] \times 100$, and the ratio of sulfate reduction and methane production was calculated as $\mathrm{S} / \mathrm{M}$.

\section{Microbial analyses \\ Genomic DNA extraction and purification}

Genomic DNA was extracted using a bead-beating method [12]. DNA products were purified with the Promega Wizard DNA Clean-up System (Promega, USA) and were stored at $-80^{\circ} \mathrm{C}$.

\section{T-RFLP analysis and clone library construction}

For T-RFLP analysis, the archaeal and bacterial $16 \mathrm{~S}$ rRNA gene fragments were amplified using the primer sets A109F/A934R and B27F/B907R, respectively, where the $5^{\prime}$ ends of primers B27f and A934r were labeled with 6-carboxyfluorescein (FAM) [12]. The PCR products were purified with the TIAN Universal DNA Purification
Kit (Tiangen, China) and were digested at $37{ }^{\circ} \mathrm{C}$ using HaeIII for bacterial DNA (TakaRa, Japan) and at $65{ }^{\circ} \mathrm{C}$ using TaqI for archaeal DNA (TakaRa, Japan) [12, 34]. Semi-quantitative DNA fragment analysis was performed as previously reported [12]. The primers and PCR used to construct the archaeal 16S rRNA gene clone library were the same as for the T-RFLP analysis, except that labelfree primers were used [12].

\section{MiSeq and bioinformatics analysis of bacterial 16S rRNA gene fragments}

The bacterial primers 515F (5'-GTGYCAGCMGCCGCGGTA-3') and 909R (5'-CCCCGYCAATTCMTTTRAGT-3') were used for high-throughput sequencing of 16S rRNA gene PCR amplicons. The PCR mixture and program were described previously [71], and sequencing was performed on the Illumina MiSeq platform. Paired-end reads were merged using FLASh v1.2.9 [72] and were quality-filtered using Trimmomatic v0.32 [73]. Chimeras were removed using the Uchime algorithm and Usearch $v$ 8.1.1861 [74]. The sequence reads in each sample were normalized using daisychopper.pl (http://www.festinalente.me/bioinf/downloads/daisychopper. pl). OTUs were clustered at $97 \%$ identity using Qiime v1.9.1 [75]. The phylogenetic affiliations of the representative OTU sequences were assigned using RDP Classifier at a confidence level of $80 \%$ [76]. Alpha diversity indices (Chao1, Shannon and Simpson) were calculated using Qiime [75].

\section{Statistical analysis}

Principal coordinate analysis (PCoA) of the community structures was conducted in PAST (http://folk.uio.no/ ohammer/past/). The significant differences in community structures between data sets were assessed for significance with ANOSIM using PAST. Correlations between community structures and environmental factors were conducted using the R package Vegan (http:// cran.r-project.org/web/packages/vegan/index.html). One-way-analysis of variance (ANOVA), and Pearson's correlations between T-RFs and environmental factors were conducted using SPSS 17.0 software (IBM, USA). The Pearson correlation coefficient $(r)$ and the coefficient of determination $\left(R^{2}\right)$ were used to evaluate the relationship between the sulfate reduction/methane production ratio and the initial sulfate concentrations, which were also analyzed using SPSS 17.0 software (IBM, USA).

\section{Additional files}

Additional file 1: Figure S1. Residual hexadecane contents after 421 days of incubation.

Additional file 2: Table S1. High-throughput sequencing of 165 rRNA gene fragments. 


\section{Abbreviations}

SRP: sulfate-reducing prokaryote; HMN: 2,2,4,4,6,8,8-heptamethylnonane; VFA: volatile fatty acid; T-RFLP: terminal restriction fragment length polymorphism; FAM: 6-carboxyfluorescein; OTU: operational taxonomic units; PCOA: principal coordinate analysis; ANOVA: one-way-analysis of variance; $\mu_{\max }$ : maximum specific methane production rate, month ${ }^{-1} ; \delta^{13} \mathrm{CH}_{4}: \delta^{13} \mathrm{C}$ value of methane; $\delta^{13} \mathrm{CO}_{2}: \delta^{13} \mathrm{C}$ value of carbon dioxide; $a_{\mathrm{app}}$ : apparent fractionation factors.

\section{Authors' contributions}

$\mathrm{LC}$ and $\mathrm{HZ}$ conceived and designed this study. TTM and LRD performed experimental studies. MTT, LLY, and WQZ collected microbial diversity data (T-RFLP, cloning and sequencing of 16S rRNA genes). ZZ and DSF analyzed sulfate and hexadecane concentrations, respectively. JPR analyzed T-RFLP and MiSeq data. QY analyzed the carbon isotope data and revised the manuscript. LC wrote the manuscript. All authors read and approved the final manuscript.

\section{Author details}

${ }^{1}$ Key Laboratory of Development and Application of Rural Renewable Energy, Biogas Institute of Ministry of Agriculture, Section 4-13, Renmin South Road, Chengdu 610041, People's Republic of China. ${ }^{2}$ Key Laboratory of Environmental and Applied Microbiology, Chengdu Institute of Biology of Chinese Academy of Sciences, Section 4-9, Renmin South Road, Chengdu 610041 , People's Republic of China. ${ }^{3}$ Environmental Microbiology Key Laboratory of Sichuan Province, Section 4-9, Renmin South Road, Chengdu 610041, People's Republic of China. ${ }^{4}$ State Key Laboratory of Environmental Geochemistry, Institute of Geochemistry, Chinese Academy of Sciences, 99 Lincheng West Road, Guanshanhu District, Guiyang 550081, People's Republic of China. ${ }^{5}$ Anhui Normal University, 1 Beijing East Road, Wuhu 241000, People's Republic of China.

\section{Acknowledgements}

We are indebted to Dr. Zhe Lyu (University of Georgia) and Dr. Peng-fei Liu (Max-Planck-Institute for Terrestrial Microbiology) for their critical comments, constructive suggestions, and extensive and vigorous edits to this work.

\section{Competing interests}

The authors declare that they have no competing interests.

\section{Availability of supporting data}

GenBank Accession Numbers for the archaeal 16S rRNA gene sequences are KJ735834-KJ735835, KJ735839-KJ735841, KJ735844-KJ735846, KJ744060KJ744106, and KJ744148-KJ744169. The raw sequencing data from this study have been deposited in the NCBI Sequence Archive under the Biosample accession no. SAMN06318635-SAMN06318640.

\section{Consent for publication}

Not applicable.

\section{Ethics approval and consent to participate} Not applicable.

\section{Funding}

This work was supported by the National High Technology Research and Development Program of China (Grant Number 2013aa064401), the National Natural Science Foundation of China (Grant Numbers 31570009, 41173088) and the Science and Technology Innovation Project of the Chinese Academy of Agriculture Science.

\section{Publisher's Note}

Springer Nature remains neutral with regard to jurisdictional claims in published maps and institutional affiliations.

Received: 12 June 2017 Accepted: 28 August 2017

Published online: 05 September 2017

\section{References}

1. BP statistical review of world energy. 2016;48:48.
2. Muggeridge A, Cockin A, Webb K, Frampton H, Collins I, Moulds T, Salino P. Recovery rates, enhanced oil recovery and technological limits. Philos Trans A Math Phys Eng Sci. 2014;372:20120320.

3. Lewis RB. Microbial enhanced oil recovery (MEOR). Curr Opin Microbiol. 2010;13:316-20.

4. Head IM, Jones DM, Larter SR. Biological activity in the deep subsurface and the origin of heavy oil. Nature. 2003:426:344-52.

5. Milkov AV. Worldwide distribution and significance of secondary microbial methane formed during petroleum biodegradation in conventional reservoirs. Org Geochem. 2011;42:184-207.

6. Aitken CM, Jones DM, Larter SR. Anaerobic hydrocarbon biodegradation in deep subsurface oil reservoirs. Nature. 2004;431:291-4.

7. Katz BJ. Microbial processes and natural gas accumulations. Open Geol J. 2011;5:e83.

8. Gray ND, Sherry A, Hubert C, Dolfing J, Head IM. Methanogenic degradation of petroleum hydrocarbons in subsurface environments: remediation, heavy oil formation, and energy recovery. In: Allen I, Sariaslani S, Geoffrey MG, editors. Advances in Applied Microbiology, vol. 72. Cambridge: Academic Press; 2010. p. 137-61.

9. Widdel F, Knittel K, Galushko A. Anaerobic hydrocarbon-degrading microorganisms: an overview. In: Timmis KN, editor. Handbook of hydrocarbon and lipid microbiology. Springer: Berlin; 2010. p. 1997-2021.

10. Jones DM, Head IM, Gray ND, Adams JJ, Rowan AK, Aitken CM, Bennett $\mathrm{B}$, Huang $\mathrm{H}$, Brown $\mathrm{A}$, Bowler BF, et al. Crude-oil biodegradation via methanogenesis in subsurface petroleum reservoirs. Nature. 2008;451:176-80

11. Gieg LM, Duncan KE, Suflita JM. Bioenergy production via microbial conversion of residual oil to natural gas. Appl Environ Microbiol. 2008:74:3022-9.

12. Cheng L, Rui J, Li Q, Zhang H, Lu Y. Enrichment and dynamics of novel syntrophs in a methanogenic hexadecane-degrading culture from a Chinese oilfield. FEMS Microbiol Ecol. 2013;83:757-66.

13. Wang L-Y, Gao C-X, Mbadinga SM, Zhou L, Liu J-F, Gu J-D, Mu B-Z. Characterization of an alkane-degrading methanogenic enrichment culture from production water of an oil reservoir after 274 days of incubation. Int Biodeterior Biodegrad. 2011;65:444-50.

14. Parkes J. Cracking anaerobic bacteria. Nature. 1999;401:217-8.

15. Zengler K, Richnow HH, Rossello-Mora R, Michaelis W, Widdel F. Methane formation from long-chain alkanes by anaerobic microorganisms. Nature 1999:401:266-9.

16. Suflita JM, Davidova IA, Gieg LM, Nanny M, Prince RC. Chapter 10 anaerobic hydrocarbon biodegradation and the prospects for microbial enhanced energy production. In: Rafael V-D, Rodolfo Q-R, editors. Studies in surface science and catalysis, vol. 151. New York: Elsevier; 2004. p. 283-305.

17. Cheng L, Shi S, Li Q, Chen J, Zhang H, Lu Y. Progressive degradation of crude oil n-alkanes coupled to methane production under mesophilic and thermophilic conditions. PLoS ONE. 2014;9:e113253.

18. Dolfing J, Larter SR, Head IM. Thermodynamic constraints on methanogenic crude oil biodegradation. ISME J. 2008;2:442-52.

19. Bastin ES, Greer FE, Merritt CA, Moulton G. The presence of sulphate reducing bacteria in oil field waters. Science. 1926;63:21-4.

20. Mbadinga SM, Wang L-Y, Zhou L, Liu J-F, Gu J-D, Mu B-Z. Microbial communities involved in anaerobic degradation of alkanes. Int Biodeterior Biodegrad. 2011:65:1-13.

21. Jiménez N, Richnow HH, Vogt C, Treude T, Krüger M. Methanogenic hydrocarbon degradation: evidence from field and laboratory studies. J Mol Microbiol Biotechnol. 2016;26:227-42.

22. Youssef N, Elshahed MS, Mclnerney MJ. Microbial processes in oil fields: culprits, problems, and opportunities. In: Allen I, Laskin SS, Geoffrey MG, editors. Advances in applied microbiology, vol. 66. Cambridge: Academic Press; 2009. p. 141-251.

23. Orphan VJ, Taylor LT, HafenbradI D, Delong EF. Culture-dependent and culture-independent characterization of microbial assemblages associated with high-temperature petroleum reservoirs. Appl Environ Microbiol. 2000;66:700-11.

24. Guan J, Zhang BL, Mbadinga SM, Liu JF, Gu JD, Mu BZ. Functional genes (dsr) approach reveals similar sulphidogenic prokaryotes diversity but different structure in saline waters from corroding high temperature petroleum reservoirs. Appl Microbiol Biotechnol. 2014;98:1871-82. 
25. Muyzer G, Stams AJM. The ecology and biotechnology of sulphatereducing bacteria. Nat Rev Micro. 2008;6:441-54

26. Khelifi N, Amin Ali O, Roche P, Grossi V, Brochier-Armanet C, Valette O, Ollivier B, Dolla A, Hirschler-Rea A. Anaerobic oxidation of long-chain $\mathrm{n}$-alkanes by the hyperthermophilic sulfate-reducing archaeon. ISME J. 2014;8:2153-66.

27. Lovley DR, Klug MJ. Sulfate reducers can outcompete methanogens at freshwater sulfate concentrations. Appl Environ Microbiol. 1983;45:187-92.

28. Kalyuzhnyi SV, Fedorovich WV. Mathematical modelling of competition between sulphate reduction and methanogenesis in anaerobic reactors. Bioresour Technol. 1998;65:227-42.

29. Omil F, Lens P, Visser A, Hulshoff Pol LW, Lettinga G. Long-term competition between sulfate reducing and methanogenic bacteria in UASB reactors treating volatile fatty acids. Biotechnol Bioeng. 1998;57:676-85.

30. Collins AG. Chapter 8. Classification of oilfield waters. In: Collins AG, editor. Developments in petroleum science, vol. 1. New York: Elsevier; 1975. p. 253-92.

31. Siegert M, Cichocka D, Herrmann S, Gründger F, Feisthauer S, Richnow $\mathrm{H}-\mathrm{H}$, Springael D, Krüger M. Accelerated methanogenesis from aliphatic and aromatic hydrocarbons under iron- and sulfate-reducing conditions. FEMS Microbiol Lett. 2011:315:6-16.

32. Siddique T, Penner T, Klassen J, Nesbø C, Foght J. Microbial communities involved in methane production from hydrocarbons in oil sands tailings. Environ Sci Technol. 2012;46:9802-10.

33. Gray ND, Sherry A, Grant RJ, Rowan AK, Hubert CRJ, Callbeck CM, Aitken CM, Jones DM, Adams JJ, Larter SR, Head IM. The quantitative significance of Syntrophaceae and syntrophic partnerships in methanogenic degradation of crude oil alkanes. Environ Microbiol. 2011:13:2957-75.

34. Cheng L, Ding C, Li Q, He Q, Dai LR, Zhang H. DNA-SIP reveals that Syntrophaceae play an important role in methanogenic hexadecane degradation. PLOS ONE. 2013;8:e66784.

35. Callaghan AV, Davidova IA, Savage-Ashlock K, Parisi VA, Gieg LM, Suflita $J M$, Kukor JJ, Wawrik B. Diversity of benyzl- and alkylsuccinate synthase genes in hydrocarbon-impacted environments and enrichment cultures. Environ Sci Technol. 2010;44:7287-94.

36. Tan B, Dong X, Sensen C, Foght J. Metagenomic analysis of an anaerobic alkane-degrading microbial culture: Potential hydrocarbon-activating pathways and inferred roles of community members. Genome. 2013:56:599-611.

37. Embree M, Nagarajan H, Movahedi N, Chitsaz H, Zengler K. Singlecell genome and metatranscriptome sequencing reveal metabolic interactions of an alkane-degrading methanogenic community. ISME J. 2013:8:757-67.

38. Tan B, Nesbo C, Foght J. Re-analysis of omics data indicates Smithella may degrade alkanes by addition to fumarate under methanogenic conditions. ISME J. 2014;8:2353-6.

39. Qin QS, Feng DS, Liu PF, He Q, Li X, Liu AM, Zhang H, Hu GQ, Cheng L. Metagenomic characterization of Candidatus Smithella cisternae strain M82_1, a syntrophic alkane-degrading bacteria, enriched from the Shengli Oil field. Microbes Environ. 2017.

40. Siddique T, Penner T, Semple K, Foght JM. Anaerobic biodegradation of longer-chain $n$-alkanes coupled to methane production in oil sands tailings. Environ Sci Technol. 2011;45:5892-9.

41. Penger J, Conrad R, Blaser M. Stable carbon isotope fractionation by methylotrophic methanogenic archaea. Appl Environ Microbiol. 2012:78:7596-602.

42. Whiticar MJ, Faber E, Schoell M. Biogenic methane formation in marine and freshwater environments: $\mathrm{CO}_{2}$ reduction vs. acetate fermentation-isotope evidence. Geochimica et Cosmochimica Acta. 1986;50:693-709.

43. Oremland RS, Polcin S. Methanogenesis and sulfate reduction: competitive and noncompetitive substrates in estuarine sediments. Appl Environ Microbiol. 1982;44:1270-6.

44. Visser A, Beeksma I, van der Zee F, Stams AJM, Lettinga G. Anaerobic degradation of volatile fatty acids at different sulphate concentrations. Appl Microbiol Biotechnol. 1993;40:549-56.

45. Madden P, Al-Raei A, Enright AM, Chinalia FA, De Beer D, O'Flaherty V, Collins $G$. Effect of sulphate on low-temperature anaerobic digestion. Front Microbiol. 2014:5.
46. Vallero MVG, Treviño RHM, Paulo PL, Lettinga G, Lens PNL. Effect of sulfate on methanol degradation in thermophilic $\left(55^{\circ} \mathrm{C}\right)$ methanogenic UASB reactors. Enzyme Microb Technol. 2003;32:676-87.

47. DeWeerd KA, Concannon F, Suflita JM. Relationship between hydrogen consumption, dehalogenation, and the reduction of sulfur oxyanions by Desulfomonile tiedjei. Appl Environ Microbiol. 1991;57:1929-34.

48. Lovley DR, Dwyer DF, Klug MJ. Kinetic analysis of competition between sulfate reducers and methanogens for hydrogen in sediments. Appl Environ Microbiol. 1982;43:1373-9.

49. Isa Z, Grusenmeyer S, Verstraete W. Sulfate reduction relative to methane production in high-rate anaerobic digestion: microbiological aspects. Appl Environ Microbiol. 1986;51:580-7.

50. Hu Y, Jing Z, Sudo Y, Niu Q, Du J, Wu J, Li Y-Y. Effect of influent $\mathrm{COD} / \mathrm{SO}_{4}{ }^{2-}$ ratios on UASB treatment of a synthetic sulfate-containing wastewater. Chemosphere. 2015;130:24-33.

51. Li Y-Y, Lam S, Fang HHP. Interactions between methanogenic, sulfatereducing and syntrophic acetogenic bacteria in the anaerobic degradation of benzoate. Water Res. 1996:30:1555-62.

52. Jeong T-Y, Chung H-K, Yeom SH, Choi SS. Analysis of methane production inhibition for treatment of sewage sludge containing sulfate using an anaerobic continuous degradation process. Korean J Chem Eng. 2009:26:1319-22.

53. Mizuno O, Li YY, Noike T. Effects of sulfate concentration and sludge retention time on the interaction between methane production and sulfate reduction for butyrate. Water Sci Technol. 1994;30:45-54.

54. Conrad R. Quantification of methanogenic pathways using stable carbon isotopic signatures: a review and a proposal. Org Geochem. 2005;36:739-52.

55. Conrad R, Klose M. Stable carbon isotope discrimination in rice field soil during acetate turnover by syntrophic acetate oxidation or acetoclastic methanogenesis. Geochimica et Cosmochimica Acta. 2011;75:1531-9.

56. Valentine DL, Chidthaisong A, Rice A, Reeburgh WS, Tyler SC. Carbon and hydrogen isotope fractionation by moderately thermophilic methanogens. Geochimica et Cosmochimica Acta. 2004;68:1571-90.

57. Penning H, Plugge CM, Galand PE, Conrad R. Variation of carbon isotope fractionation in hydrogenotrophic methanogenic microbial cultures and environmental samples at different energy status. Glob Change Biol. 2005;11:2103-13.

58. Liu Y, Whitman WB. Metabolic, phylogenetic, and ecological diversity of the methanogenic Archaea. Ann NY Acad Sci. 2008;1125:171-89.

59. Penning H, Claus P, Casper P, Conrad R. Carbon isotope fractionation during acetoclastic methanogenesis by Methanosaeta concilii in culture and a lake sediment. Appl Environ Microbiol. 2006;72:5648-52.

60. Penning $\mathrm{H}$, Conrad R. Quantification of carbon flow from stable isotope fractionation in rice field soils with different organic matter content. Org Geochem. 2007:38:2058-69.

61. Ozuolmez D, Na H, Lever MA, Kjeldsen KU, Jørgensen BB, Plugge CM. Methanogenic archaea and sulfate reducing bacteria co-cultured on acetate: teamwork or coexistence? Front Microbiol. 2015;6:492.

62. Cheng L, Qiu TL, Li X, Wang WD, Yin X, Deng Y, Zhang H. Isolation and characterization of Methanoculleus receptaculi sp. nov. from Shengli oil field, P. R. China. FEMS Microbiol Lett. 2008;285:65-71.

63. Imachi H, Sakai S, Sekiguchi Y, Hanada S, Kamagata Y, Ohashi A, Harada H. Methanolinea tarda gen. nov., sp. nov., a methane-producing archaeon isolated from a methanogenic digester sludge. Int J Syst Evol Microbiol. 2008:58:294-301.

64. Sakai S, Imachi H, Sekiguchi Y, Tseng I-C, Ohashi A, Harada H, Kamagata Y. Cultivation of methanogens under low hydrogen conditions by using the coculture method. Appl Environ Microbiol. 2009;75:4892-6.

65. Nobu MK, Narihiro T, Rinke C, Kamagata Y, Tringe SG, Woyke T, Liu W-T. Microbial dark matter ecogenomics reveals complex synergistic networks in a methanogenic bioreactor. ISME J. 2015;9:1710-22.

66. Callaghan AV, Morris BEL, Pereira IAC, McInerney MJ, Austin RN, Groves JT, Kukor JJ, Suflita JM, Young LY, Zylstra GJ, Wawrik B. The genome sequence of Desulfatibacillum alkenivorans AK-01: a blueprint for anaerobic alkane oxidation. Environ Microbiol. 2012;14:101-13.

67. Kuever J. The Family Desulfobacteraceae. In: Rosenberg E, DeLong EF, Lory S, Stackebrandt E, Thompson F, editors. The Prokaryotes: Deltaproteobacteria and Epsilonproteobacteria. Springer: Berlin; 2014. p. 45-73.

68. Powell GE. Interpreting gas kinetics of batch cultures. Biotechnol Lett. 1983:5:437-40 
69. Ma TT, Cheng L, Zheng ZZ, Qin Q, Dai LR, Zhang H. Effects of pH buffers on methanogenesis and methanogenic community in the cultures amended with acetate. Acta Microbiologica Sinica (In Chinese). 2014;54:1453-61.

70. So CM, Young LY. Isolation and characterization of a sulfate-reducing bacterium that anaerobically degrades alkanes. Appl Environ Microbiol. 1999;65:2969-76.

71. Li J, Rui J, Pei Z, Sun X, Zhang S, Yan Z, Wang Y, Liu X, Zheng T, Li X. Straw- and slurry-associated prokaryotic communities differ during co-fermentation of straw and swine manure. Appl Microbiol Biotechnol. 2014:98:4771-80

72. Magoc T, Salzberg SL. FLASH: fast length adjustment of short reads to improve genome assemblies. Bioinformatics. 2011;27:2957-63.
73. Bolger AM, Lohse M, Usadel B. Trimmomatic: a flexible trimmer for Illumina sequence data. Bioinformatics. 2014;30:2114-20.

74. Edgar RC, Haas BJ, Clemente JC, Quince C, Knight R. UCHIME improves sensitivity and speed of chimera detection. Bioinformatics. 2011;27:2194-200.

75. Caporaso JG, Kuczynski J, Stombaugh J, Bittinger K, Bushman FD, Costello EK, Fierer N, Pena AG, Goodrich JK, Gordon JI. QIIME allows analysis of high-throughput community sequencing data. Nat Meth. 2010;7:335-6.

76. Wang Q, Garrity GM, Tiedje JM, Cole JR. Naïve bayesian classifier for rapid assignment of rRNA sequences into the new bacterial taxonomy. Appl Environ Microbiol. 2007;73:5261-7.

\section{Submit your next manuscript to BioMed Central and we will help you at every step:}

- We accept pre-submission inquiries

- Our selector tool helps you to find the most relevant journal

- We provide round the clock customer support

- Convenient online submission

- Thorough peer review

- Inclusion in PubMed and all major indexing services

- Maximum visibility for your research

Submit your manuscript at www.biomedcentral com/submit 